Ethiopian Journal of Environmental Studies \& Management 8(3): 290 - 300, 2015.

ISSN:1998-0507

Submitted: January 20, 2015

doi: http://dx.doi.org/10.4314/ejesm.v8i3.6

Accepted: March 26, 2015

\title{
UPPER TROPOSPHERIC AND STRATOSPHERIC OZONE OVER EQUATORIAL EAST AFRICA; CASE STUDY OF NAIROBI COUNTY, KENYA
}

\author{
*Shilenje, Z.W., ${ }^{1}$ Ongoma, V.2,3 AND Ogwang, B.A.2,4 \\ ${ }^{1}$ Kenya Meteorological Service, P.O. Box 30259-00100, Nairobi -Kenya \\ ${ }^{2}$ College of Atmospheric Science, Nanjing University of Information Science and \\ Technology, Nanjing, Jiangsu, 210044, P.R. China \\ ${ }^{3}$ Department of Meteorology, South Eastern Kenya University, P.O. Box 170-90200, Kitui- \\ Kenya \\ ${ }^{4}$ Uganda Meteorological Agency, P.O. Box 7025, Kampala - Uganda
}

\begin{abstract}
Ozonesonde measurements over Nairobi, Kenya are presented for the period $2000-2014$. Ozone concentration is influenced by anthropogenic activities, calling for its continuous monitoring since it affects the climate system and human health. The study utilizes weekly ozonesonde flights, winds and RH from ERA-interim gridded data. The results indicate that the tropopause over Nairobi is approximately $1.3 \mathrm{~km}$ in depth. Ozone exhibits a negative trend upwards within the troposphere, up until the tropopause. There is a high increase in the lower stratosphere, peaking in the mid stratosphere. The maximum ozone value of 13.04 ppb is found at a pressure of 20 hpa and approximately, 80\% of ozone is found in the stratosphere. The June-August season experiences the highest ozone levels in the low levels and December - February the highest concentration in upper levels as compared to the other seasons. Easterlies are predominant in the lower troposphere, up to about $500 \mathrm{mb}$, westerlies in the mid troposphere and again, easterlies in upper troposphere, extending into the lower stratosphere, commonly known 'steering winds' in this region.
\end{abstract}

Key Words: Ozone, Ozonesonde, Stratosphere, Nairobi

\section{Introduction}

Ozone $\left(\mathrm{O}_{3}\right)$ gas exists at various heights throughout the atmosphere. Studies (Parrish et al., 2009; Sitch et al., 2007; Vingarzan, 2004) observe that tropospheric $\mathrm{O}_{3}$ concentration is increasing at a high rate; this is attributed to increase in anthropogenic precursor emissions. According to IPCC (2013) stratospheric ozone (SO) is key in climate studies since it influences the climate in terms of climate feedback and subsequent temperature modulation both within the atmosphere and at the earth's surface. The ozonesonde measurement technique; a ground-based measurement of ozone provides detailed information on the vertical distribution ozone in the troposphere and lower stratosphere. In Kenya, $\mathrm{O}_{3}$ is monitored at three sites: Nairobi Dagortetti, Chiromo Campus and Mt. Kenya. The trend in tropospheric ozone over Nairobi and Mt. Kenya stations have been studied by Shilenje and Ongoma (2014) and Henne et al., (2008) respectively. Shilenje and Ongoma (2014) finds that surface ozone levels are low with a one-month time lag from the onset of long rains while Henne et 
al., (2008) observes that at Mt. Kenya, a site free of anthropogenic emissions, can be representative of different catchment areas at different times of the year.

Nairobi County is located in the tropics; within $1^{\circ} 9^{\prime} \mathrm{S}, 1^{\circ} 28^{\prime} \mathrm{S}$ and $36^{\circ} 4^{\prime} \mathrm{E}, 37^{\circ}$ $10^{\prime} \mathrm{E}$. It generally receives bimodal rainfall mainly influenced by the migratory trend of the Inter-Tropical Convergence Zone (ITCZ) (Mukabana and Pielke, 1996). The 'short' rains are observed in the October - December (OND) and the 'long' rains in March- May (MAM). June to July (JJA) season is normally cool and wet while late December to February (DJF) is characterised by warm and dry conditions (Okoola, 1996). The predominant low-level winds over the region are easterlies (Ongoma et al., 2013; Opijah et al., 2007; Okoola, 1999).

According to World Health Organization (WHO), the role of SO, which contains about 90 per cent of the ozone in the atmosphere, is absorbing harmful ultraviolet radiation before it reaches the planet's surface (WHO, 1994). Although formation of ozone in the stratosphere is fairly understood (Mauersberger, 1981), the mechanisms for ozone loss are considerably more complicated. The ozonedepleting substances are introduced in the stratosphere by natural and anthropogenic activities (Henne et al., 2008; Ravishankara et al., 2009).The reduction in production of ozone depleting substances has been linked to a slowdown on in the depletion of the upper stratosphere (Tripathi et al., 2013).

The role of SO depletion on climate change cannot be underestimated, according to Meehl et al., (2007), the Coupled Model Inter-comparison Project (CMIP3) model integrations provided some evidence that depletion of SO may have a role to play in southern hemisphere climate change. The changes in the SO in the higher latitudes particularly in the northern hemisphere have been extensively studied (Tripathi et al., 2013) unlike lower latitudes like Nairobi except for the work undertaken by Southern Hemisphere Additional Ozonesondes (SHADOZ) network (Thompson et al., 2011).

This study reports the factors governing the variation of upper tropospheric and SO including seasonality and vertical distribution over Nairobi County. The study also looks into vertical variation of temperature and relative humidity $(\mathrm{RH})$.

\section{Materials and Methodology}

The data used in the study is the weekly ozonesonde flight data from Kenya Meteorological Service (KMS) covering the years 2000 - 2014. Ozone flight data is measured at Dagoretti Corner; latitude $1.30^{\circ} \mathrm{S}$ and longitude $36.76^{\circ} \mathrm{E}$. The World Meteorological Organisation (WMO) recognises the vital role of ozonesondes (Figure 1a) in monitoring stratospheric and tropospheric ozone (WMO, 2014), data that is used in calibrating satellites and other space borne devices. Ozonesondes used over Nairobi are small, light instruments attached on a radiosonde (Figure 1b) and both flown up in the atmosphere using a $1500 \mathrm{~g}$ hydrogen-laden balloon. The radiosonde has sensors for weather elements: temperature, pressure, humidity and interpolates wind speed and direction from its changing positions. The radiosonde also has electronic capability to interfacefor data transmission back to the computing systems on the ground. Figure $1 \mathrm{~b}$ shows a radiosonde, RS92, with the following parts: 1- global positioning antenna system for wind profiling, 2 - battery case, 3 - sensor interface capsule, 4 -antenea, 5 - thermistor for temperature sensing, 6 -hygrocarp for humidity, 7 - sensor boom, 8- GC25 interface ground checking device and an inbuilt aneroid pressure sensor. 


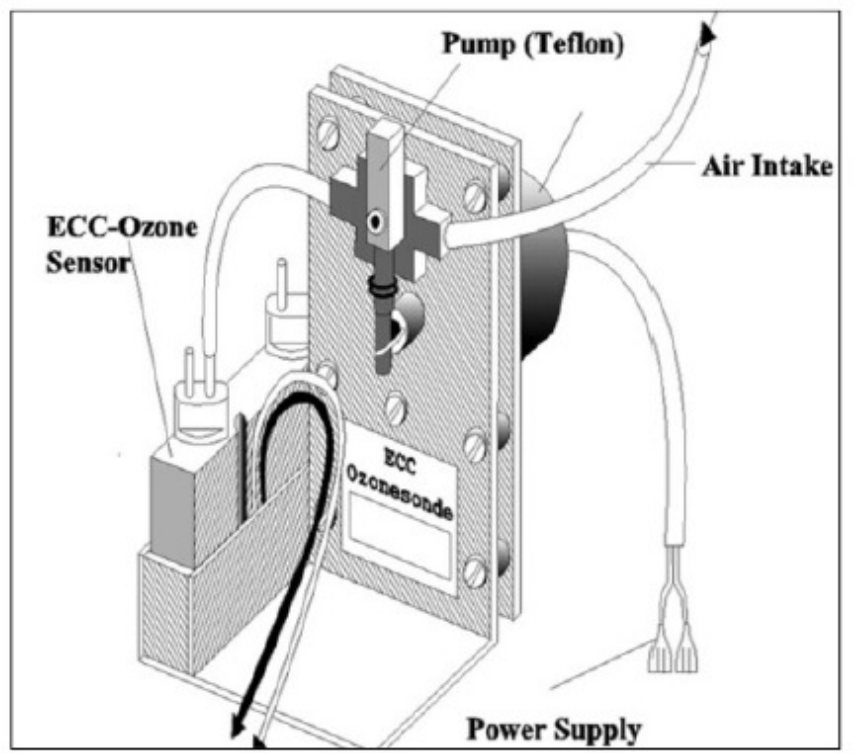

(a)

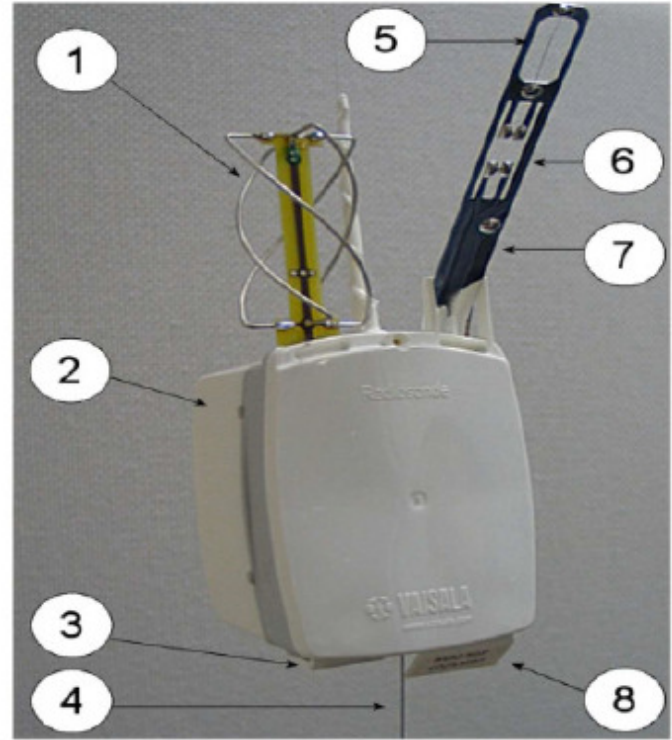

(b)

(Source: Thompson et al., 2011)

Figure 1: Ozonesonde and radiosonde RS292 used over Nairobi

The ozonesondes contain a pump, for sucking in air, 2 tubes forming the electrochemical cells that are fed with potassium iodide solution that reacts with ozone gas. The chemical reaction generates among other chemical compounds, an electric current. The current is directly proportional to the amount of ozone present.

Mean zonal wind component $(u)$ over Nairobi is calculated from the vertical wind profile using Equation 1.

$u=\bar{u} * \sin \theta$

Where $u$ is the zonal wind component, $\bar{u}$ is the mean wind speed at the vertical level and $\theta$ is the acute angle of the wind direction in the respective quadrands, except in quadrant 3 where the trigonometric function used was cosine in Equation 1.

The zonal and meridional winds and $\mathrm{RH}$ from ERA-interim, gridded at 0.75 degree resolution (Dee et al., 2011) was used in this study to generate a 14 year wind and $\mathrm{RH}$ climatology respectively.

\section{Results and Discussion}

Table 1 shows the 248 ascents used in this study undertaken at Nairobi every Wednesday of the week or on Thursday in case of ascend failure on Wednesday. The soundings are taken around 0900hrs.

Table 1: Monthly ascents

\begin{tabular}{llllll}
\hline & 2010 & 2011 & 2012 & 2013 & 2014 \\
\hline Jan & 4 & 4 & 4 & 5 & 3 \\
Feb & 4 & 4 & 5 & 4 & 4 \\
Mar & 5 & 5 & 4 & 4 & 4 \\
Apr & 4 & 4 & 4 & 4 & 5 \\
May & 4 & 2 & 4 & 5 & 3 \\
Jun & 4 & 4 & 5 & 5 & 4 \\
Jul & 5 & 4 & 4 & 5 & 5 \\
Aug & 4 & 5 & 6 & 3 & 4 \\
Sep & 4 & 3 & 5 & 4 & 4 \\
Oct & 4 & 4 & 4 & 5 & 5 \\
Nov & 4 & 5 & 4 & 6 & 3 \\
Dec & 5 & 4 & 4 & 2 & 5 \\
Total & 51 & 48 & 53 & 52 & 46 \\
\hline
\end{tabular}

Figure 2 shows on average the balloon ascent rate over Nairobi is about $5 \mathrm{~m} / \mathrm{s}$ rising to an average height of $32 \mathrm{~km}$ and attaining an average minimum pressure height of $8.2 \mathrm{mb}$. 


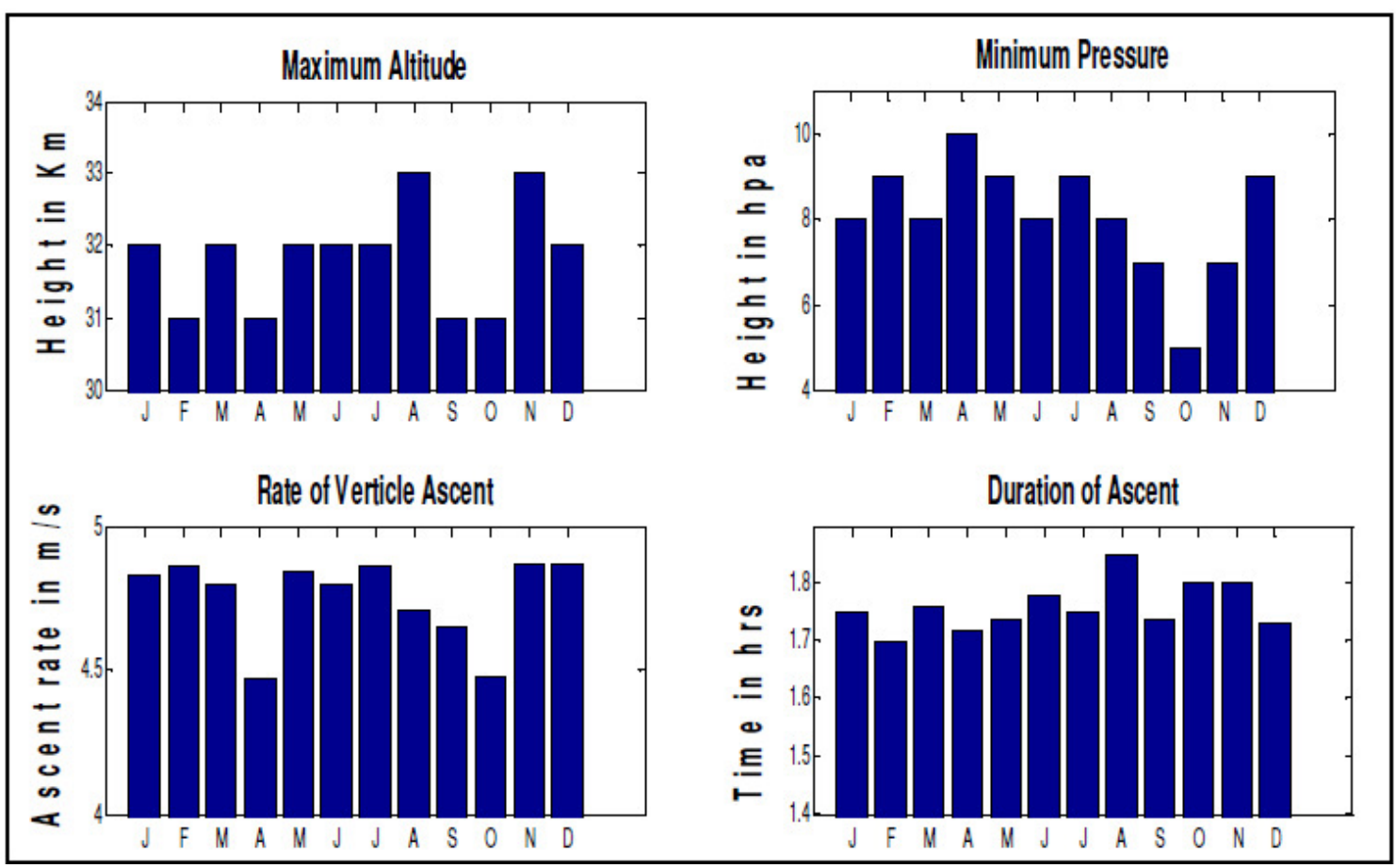

Figure 2: Sample statistics obtained from the data sets

From the data, on average it takes about 1 hour and 45 minutes to complete a vertical ascent (Figure 2).

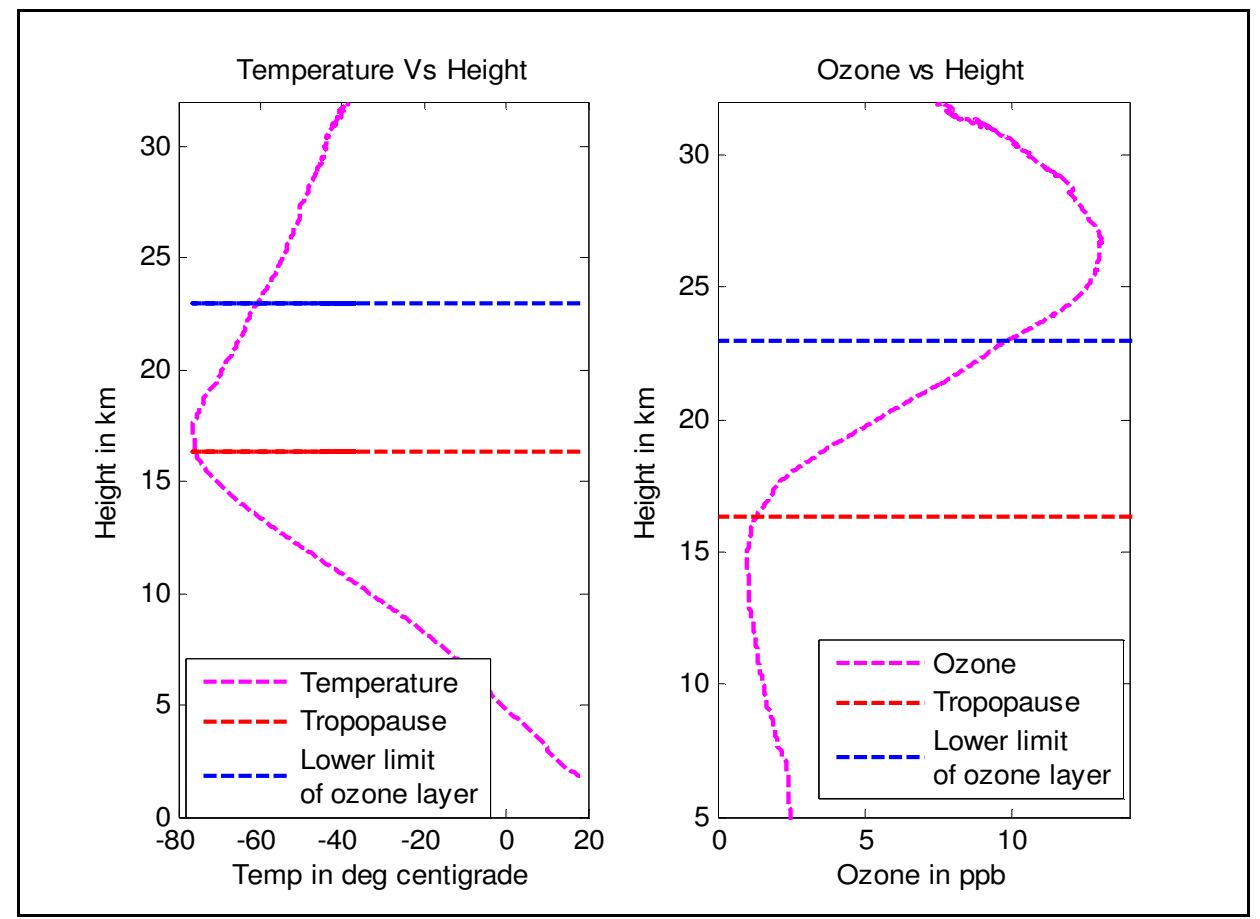

Figure 3: Mean vertical variation; (a) temperature, (b) Ozone over Nairobi, 2010-2014

Figure 3 shows temperature and ozone flight data. The analysis, (Figure 3a), shows a decreasing temperature trend within the troposphere up to $110 \mathrm{mb}(16.3 \mathrm{~km})$ level where it becomes constant up to $88 \mathrm{mb}$ $(17.6 \mathrm{~km})$ level. The average flight data is 
in agreement with observations made by other studies (e.g. Thomson et al., 2011; Gettelman et al., 2010) on the average level of tropical tropopause being located at close $100 \mathrm{mb}$ level with a height ranging from 12 - $19 \mathrm{~km}$. The observed layer between $110 \mathrm{mb}(16.3 \mathrm{~km})$ level and $88 \mathrm{mb}(17.6 \mathrm{~km})$ level represents the tropopause, which this data suggests is about $1.3 \mathrm{~km}$ in depth. Although, Pidwirny (2006) found out that the average depth of the troposphere is approximately $11 \mathrm{~km}$ within the tropics, this study reveals, on average, over Nairobi it extends to about $16 \mathrm{~km}$.

Figure $3 \mathrm{a}$ further shows temperature increases within the lower stratosphere. The ozone, (Figure 3b), shows small values, with negative trend upwards within the troposphere, up until the tropopause. Within the tropopause, there is a gentle increase in the ozone concentration and a sharp increase in the lower stratosphere, peaking in the mid stratosphere. The maximum ozone value of $13.04 \mathrm{ppb}$ is found at a pressure of $20 \mathrm{hpa}$ (about $27 \mathrm{~km}$ ). The ozone layer, with the highest concentration of ozone, is within $40-10 \mathrm{mb}$ (about $23-30$ $\mathrm{km}$ ) above mean sea level (amsl). The ozone layer is therefore, about $23 \mathrm{~km}$ amsl and covers a depth of about $7 \mathrm{~km}$, located in the mid stratosphere over Nairobi. The zone concentration is in agreement with Sauvage et al., (2005); a study which noted that tropospheric ozone does not exceeded 20 $40 \mathrm{ppb}$ on average.

Figure 4 shows the distribution of the RH showing an increasing trend in the first $2.5 \mathrm{~km}$, then a steady decline to about $10 \mathrm{~km}$ in the troposphere. There is an increasing kink just before the tropopause before rapidly declining to almost nought in the lower stratosphere.

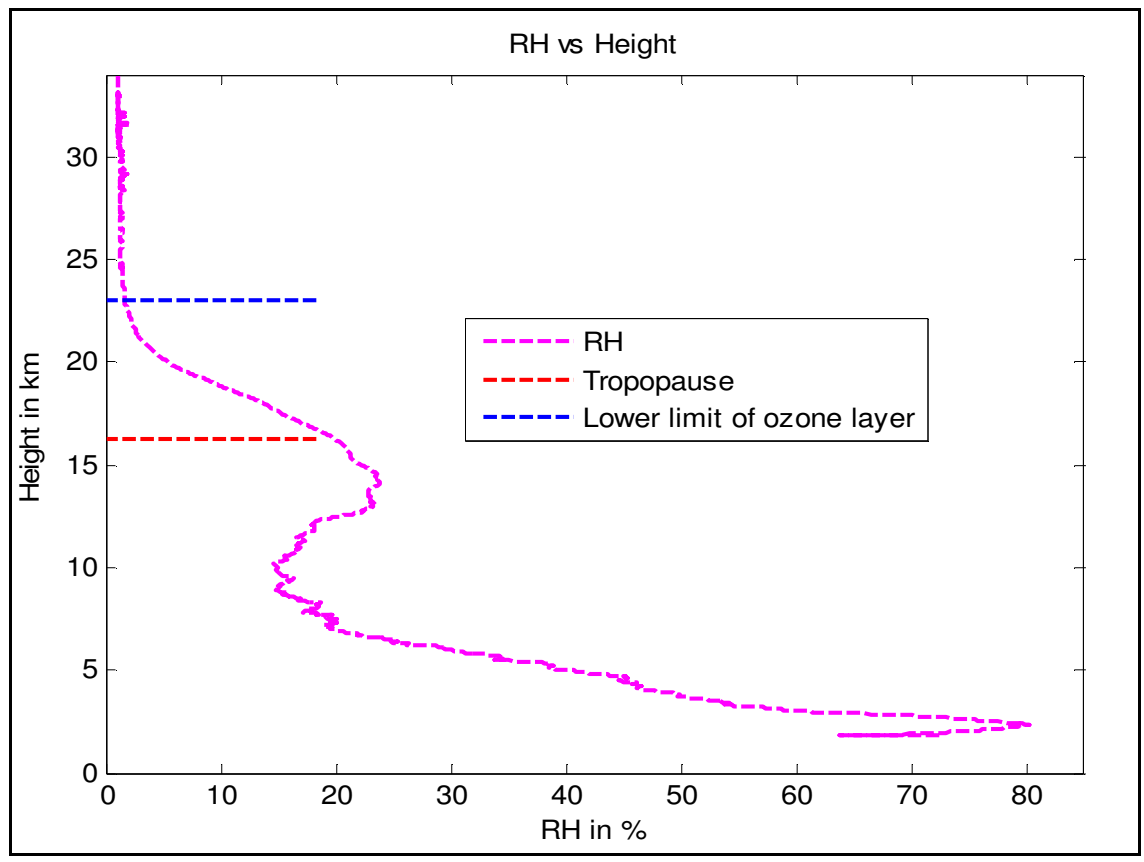

Figure 4: Mean vertical variation of RH over Nairobi, 2010-2014

The mean values in Figures 3 and 4 were decomposed into 3 months interval to correspond with different weather seasons over Kenya and Nairobi in particular. The results obtained are presented in Figures 5 and 6. 


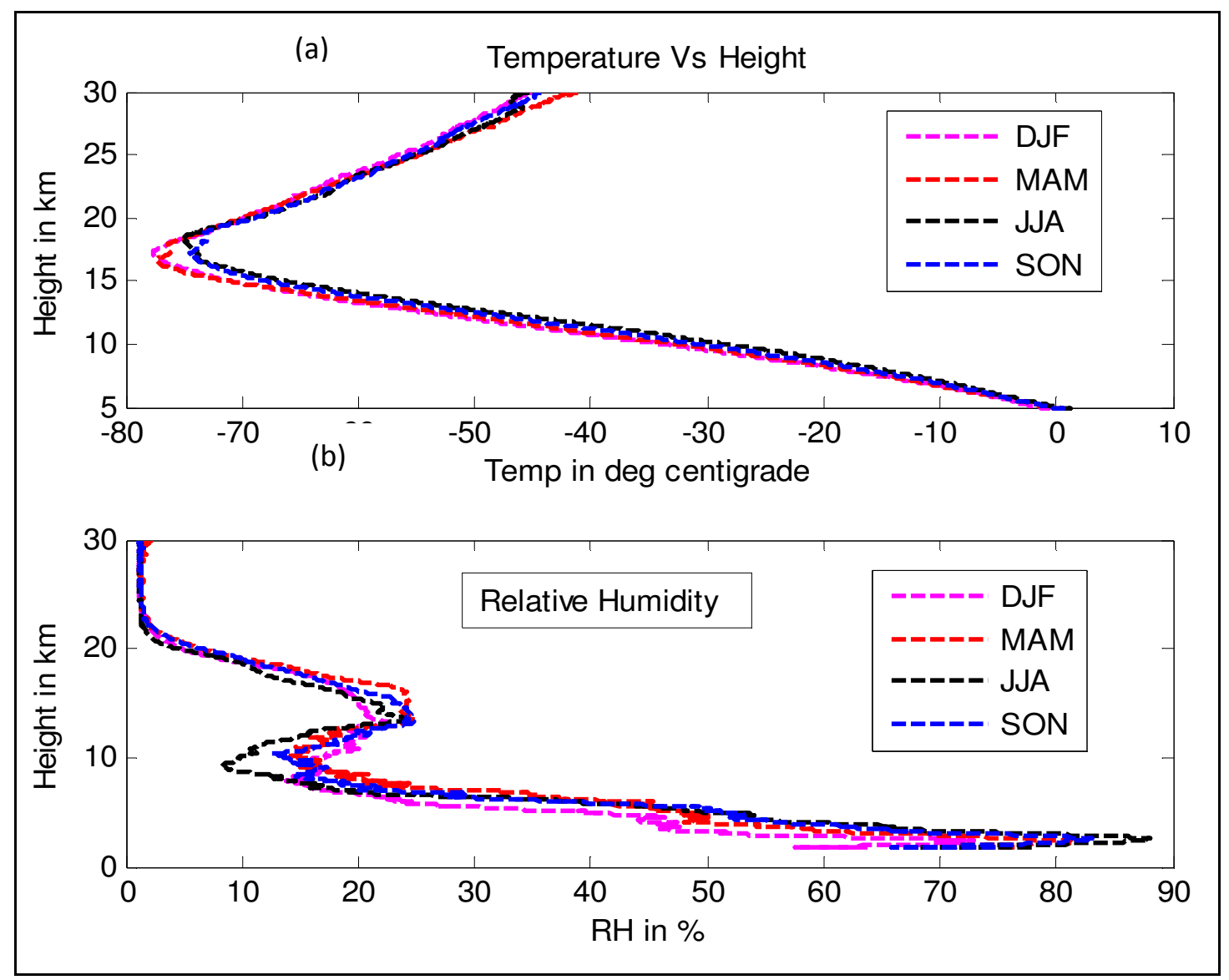

Figure 5: Mean vertical seasonal variation; (a) Temperature, (b) RH over Nairobi, 2010-2014

Figure 5a shows that there is less variation of tropospheric temperature over the seasons to the tropopause, where during MAM the temperature is lower than the other seasons. The DJF season exhibits the highest temperature throughout the troposphere. The MAM and SON seasons experience high moisture levels as compared to other seasons with DJF recording the least moisture content (Figure $5 b)$.

Figure 6 presents the mean vertical seasonal variation of ozone. Generally, the JJA season experiences the highest ozone levels in the low levels while DJF the highest concentration in upper levels as compared to the other seasons. This is partly in agreement with Pandey et al., (1992); the study demonstrated that there exist a significant positive correlation between $\mathrm{O}_{3}$ concentrations, solar radiation and temperature. There is an exception at the tropopause where higher values of ozone are reported during SON.

The variation ozone was then considered at three specific points in the atmosphere to represent lower troposphere, tropopause and the lower stratosphere. The points were chosen based on literature (Ayoma et al., 2004) and the data set that suggests that tropopause is at $99 \mathrm{mb}$ (mean of 88 and $110 \mathrm{mb}$ ), highest in stratosphere at $26 \mathrm{mb}$ (mean of 23 and $30 \mathrm{mb}$ ) and 5 metres above the ground to represent lower troposphere. The lower stratosphere is considered at $5 \mathrm{~km}$ to avoid any direct ozone reaction/formation induced by primary pollutants from the city of Nairobi. The seasonally averaged vertical ozone profiles show the highest ozone concentration at an altitude of $5 \mathrm{~km}$ during the cold-dry season. Low ozone concentration is observed during the long rain and warm-dry season at an altitude of about $26 \mathrm{~km}$. 


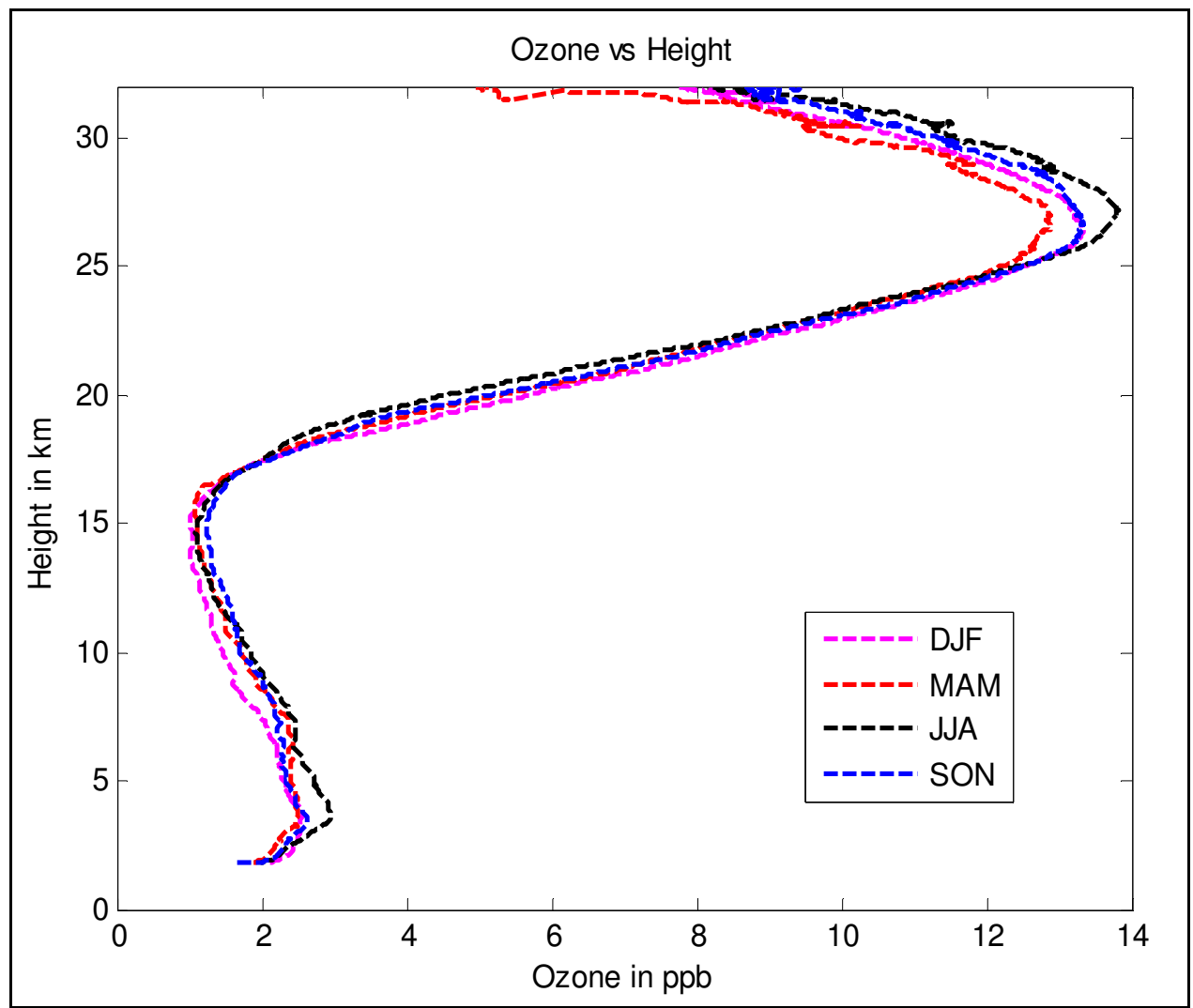

Figure 6: Mean vertical seasonal variation of Ozone over Nairobi, 2010-2014

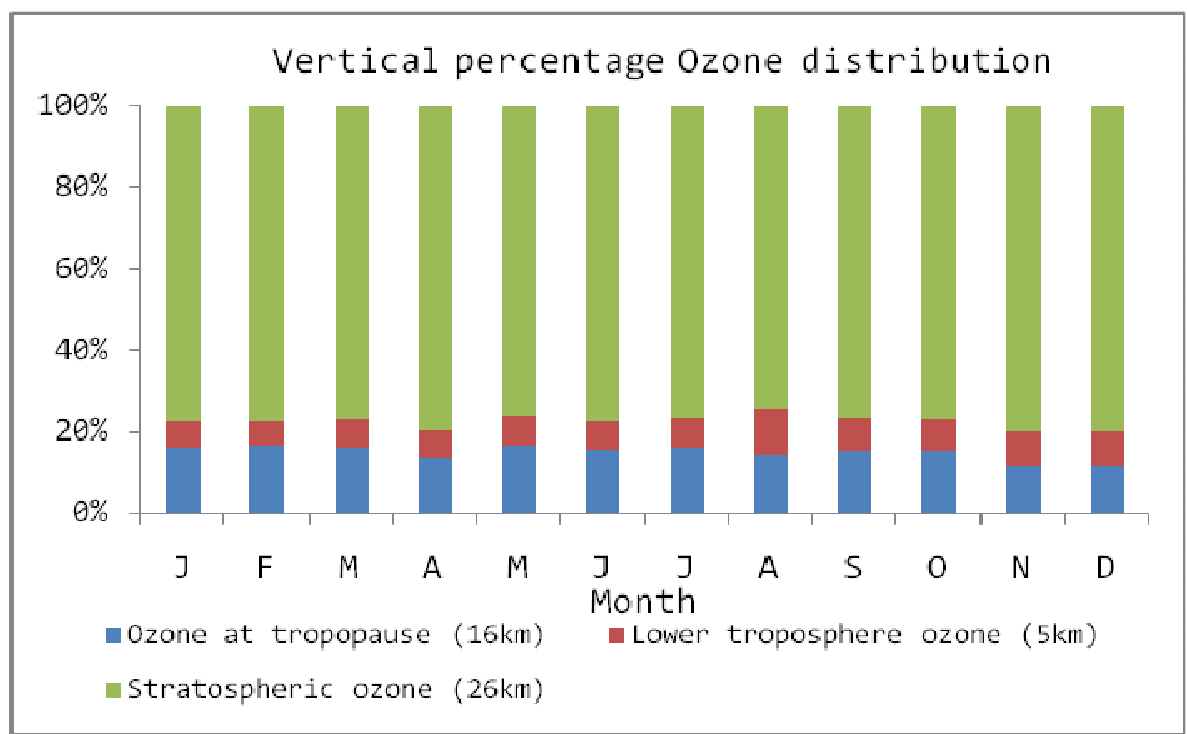

Figure 7: Temporal Vertical profile of Ozone over Nairobi, 2010-2014

Figure 7 shows the percentage vertical ozone distribution, approximately, $80 \%$ of the ozone is found in the stratosphere, $8 \%$ at the tropopause and $12 \%$ in lower stratosphere. This observation is supported by WHO (1994) that reported that up to $90 \%$ of ozone is within the stratosphere. In this study, the percentage of SO stands at $88 \%$, the distribution is fairly constant with time, except in the months of May and August that there seems a slight reduction.

The transport of ozone depleting substances, precursors and other pollutants are affected by wind, atmospheric stability 
and turbulence. The freshly emitted pollutants mix and a complicated the process of chemical reactions and continuous dilution and formation takes place (Henne et al., 2008). Figure 8 shows the mean zonal wind distribution over Nairobi. Easterlies are predominant in the lower troposphere, up to about $500 \mathrm{mb}$, westerlies in the mid troposphere and again, easterlies in upper troposphere, extending into the lower stratosphere, commonly known 'steering winds' in this region. This is because of their effect of 'steering' or advecting weather systems such convective cells or moisture in and out the region of east Africa. The observed predominant easterlies in the lower troposphere were observed by other studies (Ongoma et al., 2013; 2014).

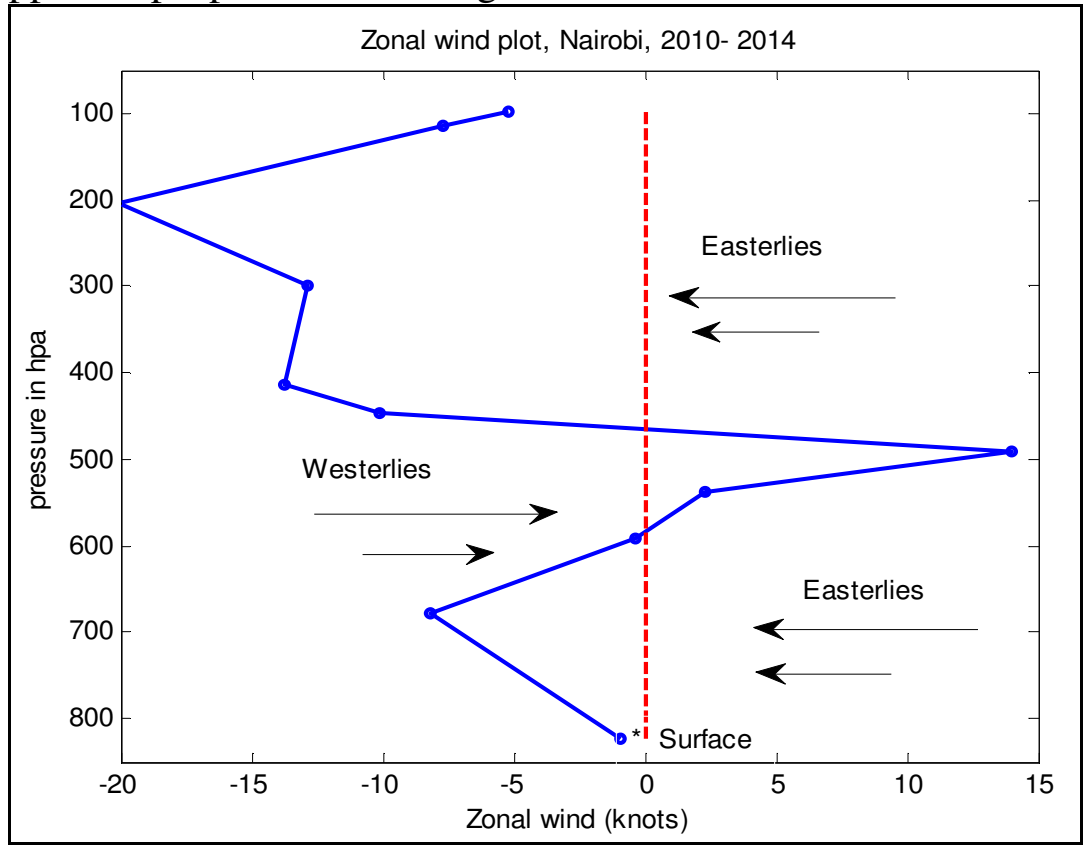

Figure 8: Nairobi zonal wind component, 2010- 2014

Ozone is depleted by dry and wet deposition on the ground and long-term transport. Figure 9 displays mean seasonal wind speed, direction and $\mathrm{RH}$ at $850 \mathrm{mb}$ pressure level (boundary layer) over east Africa. Meteorological conditions at pressure level $850 \mathrm{mb}$ are used to consider lower atmospheric conditions rather than surface conditions normally $2-10 \mathrm{~m}$ above ground.

During the MAM period, there is predominantly easterly flow (Figure 9b) from Indian Ocean contributing to high moisture content over east Africa (Figure 9f). The RH over Nairobi remains low (Figure 9e) during DJF. High RH content implies presence of a humid atmosphere is negatively correlated with ozone; similar observation was made by other studies
(Ahmad et al., 2012; Wang et al., 2014). Wind field data show notable features of south easterlies over the coast of east Africa. The winds penetrate into Nairobi during MAM, JJA and DJF but the wind vectors reverses to dry north-easterly flow during DJF. A comparison of wind speeds during different seasons shows that weak north easterlies are observed during DJF as compared to other seasons that generally experience strong easterlies (Figure 9a). The observed high concentration of ozone especially in the upper levels during DJF (Figure 6) can partly be explained by the observed weak winds. This is supported by observations made in an earlier by Odhiambo et al., (2010) in a study on motor vehicles air pollution in Nairobi. 


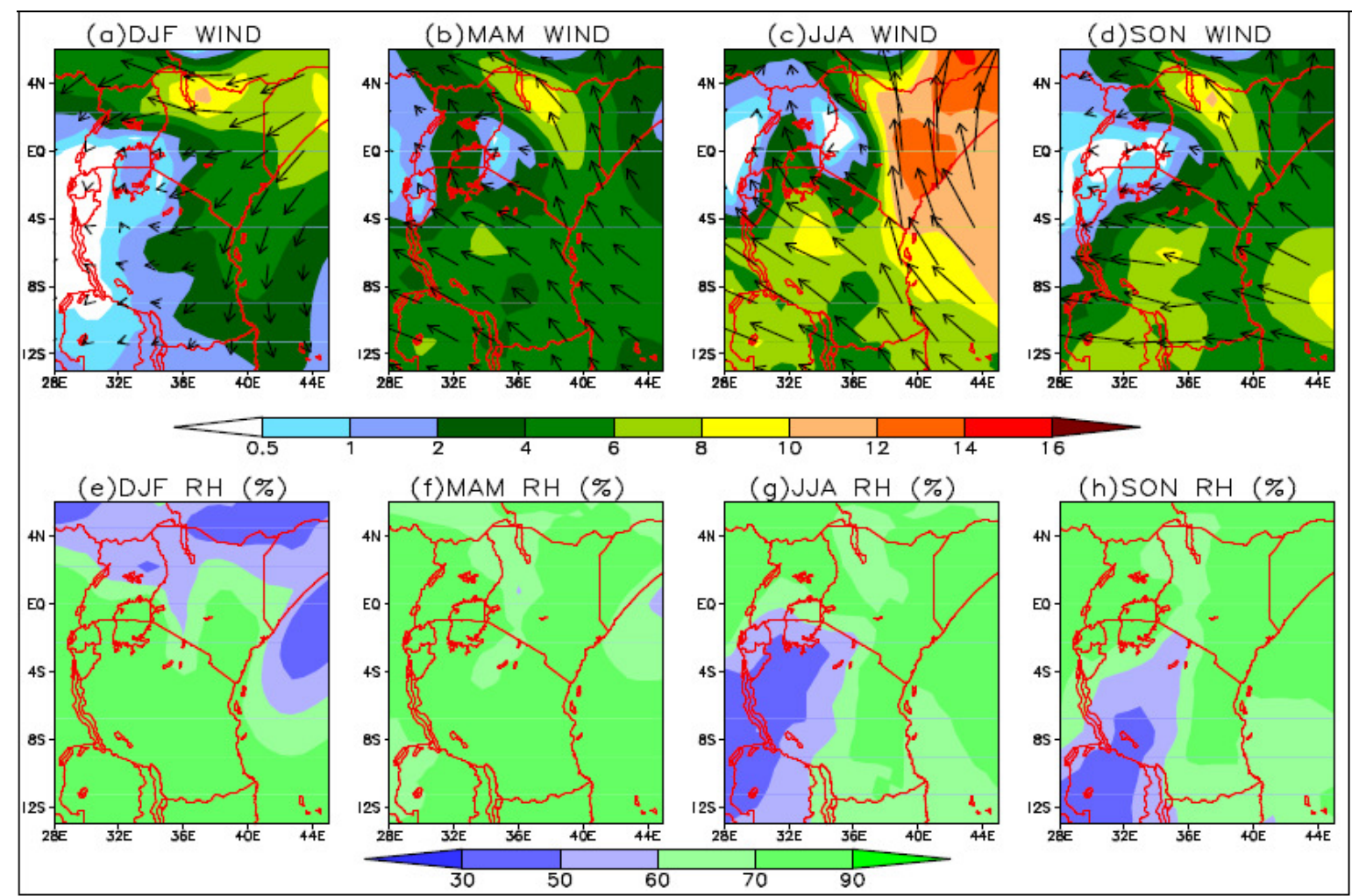

Figure 9: The mean seasonal wind speed (shaded in $\mathrm{m} / \mathrm{s}$ ) and direction (a) DJF (b) MAM (c) JJA (d) SON and the mean seasonal RH (e) DJF (f) MAM (g) JJA (h) SON. All averaged over 2000-2013.

\section{Conclusion}

The goal of this paper has been to study variation of upper tropospheric and SO, including seasonality and vertical distribution over Nairobi County. Research shows that the tropopause is about $1.3 \mathrm{~km}$ in depth. The ozone profile shows a negative trend upwards within the troposphere, up until the tropopause. The concentration is however increasing at a lower rate in the tropopause and a sharp increase in the lower stratosphere, peaking in the mid stratosphere. The maximum ozone value of $13.04 \mathrm{ppb}$ is found at a pressure of 20 hpa (about $27 \mathrm{~km}$ ). The ozone layer, with the highest concentration of ozone, is within $40-10 \mathrm{mb}$ (about $23-30$ $\mathrm{km})$ above mean sea level. Generally, the DJFseason experiences the highest ozone levels as compared to the other seasons in the upper levels. The vertical profile of ozone shows that approximately $80 \%$ of ozone is found in the stratosphere.
Easterlies are predominant in the lower troposphere, up to about $500 \mathrm{mb}$, westerlies in the mid troposphere and again, easterlies in upper troposphere, extending into the lower stratosphere, commonly known 'steering winds' in this region. Approximately $80 \%$ of the ozone is found in the stratosphere, $8 \%$ at the tropopause indicating very minimal or no depletion of SO in line with WHO (1994).

\section{Acknowledgements}

The authors express their profound gratitude to their respective institutions for creating an enabling environment to carry out the research. Special thanks go to Kenya Meteorological Service and MeteoSwiss for their support and roles in provision of data used in this study.

\section{References}

Ahmad, S.S., Aziz, N. and Fatima, N. (2012). Monitoring and Visualization 
of Tropospheric Ozone in Rural/Semi Rural Sites of Rawalpindi and Islamabad, Pakistan. Environnemental Pollution, $\quad$ 1(2): $\quad$ 75-85. doi:10.5539/ep.v1n2p75

Ayoma, W., Gilbert, L. and Bertrand, C. (2004).Variability in the observed vertical Distribution of ozone over equatorial Eastern Africa: an analysis of Nairobi Ozonesonde data 2004. Proceedings Quadrennial Ozone Symposium, $1^{\text {st }}-8^{\text {th }}$ June 2004 , Kos, Greece.

Parrish, D.D., Millet, D.B. and Goldstein, A.H. (2009). Increasing ozone in marine boundary layer inflow at the west coasts of North America and Europe. Atmospheric Chemistry and Physics, 9:1303-1323, doi:10.5194/acp-9-1303-2009.

Dee, D.P., Uppala, S.M., Simmons, AJ., Berrisford, P., Poli, P., Kobayashi, S., Andrae, U., Balmaseda, M.A., Balsamo, G., Bauer, P., Bechtold, P., Beljaars, A.C.M., van de Berg, L., Bidlot, J., Bormann, N., Delsol, C., Dragani, R., Fuentes, M., Geer, A.J., Haimberger, L., Healy, S.B., Hersbach, H., Hólm, E.V., Isaksen, L., Kållberg, P., Köhler, M., Matricardi, M., McNally, A.P., MongeSanz, B.M., Morcrett, J.J., Park, B.K., Peubey, C., de Rosnay, P., Tavolato, C., Thépaut, J.N. and Vitart, F. (2011). The ERA-Interim reanalysis: configuration and performance of the data assimilation system. Quarterly Journal of Royal Meteorological Society, 137:553-597, doi:10.1002/qj.828

Gettelman, A., Hegglin, M.I., Son, S.W., Kim, J., Fujiwara, M., Birner, T., Kremser, S., $\quad$ Rex, M., Añel,J.A., Akiyoshi, H., Austin, J., Bekki, S., Braesike, P., Brühl, C., Butchart, N., Chipperfield, M., Dameris, M., Dhomse, S., Garny, H., Hardiman, S.C., Jöckel, P., Kinnison, D.E., Lamarque, J.F., Mancini, E., Marchand, M., Michou, M., Morgenstern, O., Pawson, S., Pitari, G., Plummer, D., Pyle, J.A., Rozanov, E., Scinocca, J., Shepherd, T.G., Shibata, K., Smale, D., Teyssèdre, H., Tian, W.
(2010). Multimodel assessment of the upper troposphere and lower stratosphere: Tropics and global trends. Journal of Geophysical Research, 115, D00M08.doi: 10.1029/2009JD013638

Henne, S., Klausen, J., Junkermann, W., Kariuki, J., Aseyo, J. and Buchmann, B. (2008). Representativeness and climatology of carbon monoxide and ozone at the global GAW station Mt. Kenya in equatorial Africa. Atmospheric Chemistry and Physics,8: 3119-3139.

IPCC (2013). Climate Change 2013: The Physical Science Basis, Contribution of Working Group I to the Fifth Assessment Report of the Intergovernmental Panel on Climate Change [Stocker, T.F., D. Qin, G.K. Plattner, M. Tignor, S.K. Allen, J. Boschung, A. Nauels, Y. Xia, V. Bex and P.M. Midgley (eds.)]. Cambridge University Press, Cambridge, United Kingdom and New York, NY, USA

Mauersberger, K. (1981). Measurement of heavy ozone in the stratosphere. Geophysical Research Letters, 8(8): 935-937.

Meehl, G.A, Covey, C., Delworth, T., Latif, M., McAvaney, B., Mitchell, J.F.B, Stouffer, R.J, Taylor, K.E. (2007).The WCRP CMIP3 multimodel dataset. Bulletin of American Meteorological Society, 88:1383-1394.

Mukabana, J.R. and Pielke, R.A. (1996). Investigating the influence of synoptic-scale monsoonal winds and mesoscale circulations on diurnal weather patterns over Kenya using a mesoscale numerical model. Monthly Weather Review, 124: 224-243.

Odhiambo, G.O., Kinyua, A.M., Gatebe, C.K, Awange, J. (2010). Motor Vehicles Air Pollution in Nairobi, Kenya.Res. Journal of Environment and Earth Science, 2(4): 178-187.

Okoola, R.E. (1999). A diagnostic study of the eastern Africa monsoon circulation during the northern 
hemisphere spring season. International Journal Climatology, 19: 143-168.

Okoola, R.E. (1996). Space-time Characteristics of the ITCZ over equatorial Eastern Africa during anomalous rainfall years (unpublished doctoral dissertation). University of Nairobi, Kenya.

Ongoma, V., Muthama, J.N. and Gitau, W., (2013). Evaluation of Urbanization Influences on Urban Winds of Kenyan Cities. Ethiopian Journal Environmental Studies and Management 6(3):223-231. http://dx.doi.org/10.4314/ejesm.v6i3.1

Ongoma, V., Otieno, G., Onyango, A.O. (2014). An investigation of the transport and dispersion of atmospheric pollutants over Nairobi City. Journal of Environment and Agricultural Sciences, 110.

Opijah, F.J., Mukabana, J.R., Ng'ang'a, J.K. (2007).Rainfall Distribution over Nairobi Area.Journal Kenya Meteorological Society, 1(1) 3-13.

Pandey, J., Agrawal, M., Khanam, N., Narayan, D. and Rao, D.N. (1992). Air polluant concentrations in varanasi, India. Atmospheric Environment, 26(1): 91-98.

Pidwirny, M. (2006). The Layered Atmosphere. Fundamentals of Physical Geography, $\quad 2^{\text {nd }}$ Edition. Retrieved November $\quad 11^{\text {th }}, \quad 2014$, from http://www.physicalgeography.net/fund amentals/7b.html.

Ravishankara, A.R., Daniel, J.S., Portmann, R.W. (2009). Nitrous oxide $\left(\mathrm{N}_{2} \mathrm{O}\right)$ : the dominant ozone-depleting substance emitted in the $21^{\text {st }}$ century. Science, 326(5949) 123-125.

Sauvage, B., Thouret, V., Cammas, J.P., Gheusi, F., Athier, G. and N'ed'elec, P.(2005). Tropospheric ozone over Equatorial Africa: regional aspects from the MOZAIC data. Atmospheric Chemistry and Physics, 5311-335
Shilenje, Z.W. and Ongoma, V. (2014). Observed surface ozone trend in the year 2012 over Nairobi, Kenya. Atmósfera, 27(4): 377-384

Sitch, S., Cox, P.M., Collins, W.J. and Hunting for, D.C. (2007). Indirect radiative forcing of climate change through ozone effects on the landcarbon sink. Nature, 448: 791-794. http://dx.doi.org/10.1038/nature06059

Thompson, A.M., Oltmans, S.J., Tarasick, D.W., von der Gathen, P., Smit, H.G., Witte, J.C. (2011). Strategic ozone sounding networks: Review of design and accomplishments. Atmospheric Environment, 45(13): 2145-2163.

Tripathi, O.P., Jennings, S.G., O'Dowd C.D., Lambkin, K.P., Moran, E. (2013). Measurements of stratospheric ozone at a mid-latitude observing station Valentia, Ireland $\left(51.94^{\circ} \mathrm{N}, 10.25^{\circ} \mathrm{W}\right)$, using ground-based and ozonesonde observations from 1994 to 2009. Journal of Atmospheric Chemistry, 70(4):297-316.

Vingarzan, R. (2004). A review of surface ozone background levels and trends.Atmos. Environ., 38, 34313442.http://dx.doi.org/10.1016/j.atmos env.2004.03.030

Wang, Y., Ying, Q., Hu, J., Zhang, H. (2014). Spatial and temporal variations of six criteria air pollutants in 31provincial capital cities in China during 2013 - 2014. Environment International 73: $413 \quad-\quad 422$. http://dx.doi.org/10.1016/j.envint.2014.08 .016

WMO (2014). Global Ozone Research and Monitoring Project - Report No. 56. http://www.esrl.noaa.gov/csd/assessm ents/ozone/2014/ (Accessed on $01.12 .2014)$.

WHO (1994).Environmental health criteria 160: ultraviolet radiation. p.352 Geneva. 